\title{
Proteolysis in the Subtropical Woody Tree Anadenanthera colubrina (Angico) Seeds during and after Germination
}

\author{
Douglas Barduche1, Kalynka G. do Livramento', Wagner A. S. Judice², Luciano V. Paiva1, \\ Luiz Juliano Neto ${ }^{3}$, Renato M. Guimarães ${ }^{4}$ \\ ${ }^{1}$ Laboratório Central de Biologia Molecular (LCBM), Federal University of Lavras (UFLA), Lavras, Brazil \\ ${ }^{2}$ Centro Interdisciplinar de Investigação Bioquímica (CIIB), University of Mogi das Cruzes (UMC), Mogi das Cruzes, Brazil \\ ${ }^{3}$ Instituto Nacional de Farmacologia (INFAR), Federal University of São Paulo (UNIFESP), São Paulo, Brazil \\ ${ }^{4}$ Laboratório de Análise de Sementes (LAS), Federal University of Lavras (UFLA), Lavras, Brazil \\ Email: douglasbarduche@gmail.com,kalynkagabriella@yahoo.com.br, luciano@dqi.ufla.br,wagneras@umc.br, \\ ljuliano@terra.com.br, renatomg@dag.ufla.br
}

How to cite this paper: Barduche, D., do Livramento, K.G., Judice, W.A.S., Paiva, L.V., Neto, L.J. and Guimarães, R.M. (2018) Proteolysis in the Subtropical Woody Tree Anadenanthera colubrina (Angico) Seeds during and after Germination. American Journal of Plant Sciences, 9, 1169-1190. https://doi.org/10.4236/ajps.2018.96088

Received: March 16, 2018

Accepted: May 18, 2018

Published: May 21, 2018

Copyright (c) 2018 by authors and Scientific Research Publishing Inc. This work is licensed under the Creative Commons Attribution International License (CC BY 4.0).

http://creativecommons.org/licenses/by/4.0/

\begin{abstract}
Proteolysis of seed storage proteins (SSP) during germination provides a steady supply of amino acids to the embryo development into seedling. This process is coordinated by different peptidases that act sequentially and overlaid mode. These enzymes are an ancient group evolved separately in a wide structural and functional diversity and have many applications in medicine, pharmacy and industry. However, the knowledge about seed peptidases during germination was obtained from studies almost restricted to the cultivated species. This restriction implies caution about generalizations made from these studies, as well limits the biological knowledge about plant kingdom and technological use from plant peptidases. In this work, a scan of the proteolytic activity was held in germinating seeds of a leguminous subtropical woody tree. Eleven proteolytic activities were detected in protein extracts from embryonic axis and cotyledons. The presence and intensity of these activities varied over time and between these tissues. There was indication that aspartyl-endopeptidases (phytepsins) and cysteine-carboxypeptidases (plant cathepsins) were involved in A. colubrina SSP hydrolysis. These peptidases differ to that commonly involved in germination of the cultivated leguminous. In addition, one of detected phytepsins showed stability on $\mathrm{pH}$ scale, which is important for industrial uses. There was also detected a metallo-carboxypeptidase activity, which has been not described in plants. These peptidases must be isolated to confirm or not these indications. However, these data indicate the biological and technological importance of extending the studies about plant peptidases on a diverse genetic basis.
\end{abstract}




\section{Keywords}

Plant Peptidases, Leguminous Trees, Biodiversity, Biotechnology

\section{Introduction}

The proteolysis of the seed storage proteins (SSP) during germination is crucial to seedling establishment. This process, which is activated at seed hydration and remains active after germination, is coordinated by joint activity of different peptidases. These hydrolases are expressed in temporal- and tissue-specific way. They are accumulated in embryonic axis and reserve tissues during seed maturation, as well synthesized during and after germination. Thus, being activated or synthesized, these enzymes sequentially hydrolyze SSP and provide continuous amino acids supply for resumption of embryonic axis development until seedling establishment [1] [2] [3] [4] [5].

The explanatory models of this proteolytic process were based from studies with some cultivated species. Despite the validity of these models, the restriction of studies to these few and genetically standardized plants limits the biological knowledge about proteolysis during germination and other plant proteolytic processes. Maybe is enough to consider the close genetic base that the model plants represent in front of the angiosperms diversity [250,000 species in the world; 50,000 in Brazil] [6] and of the peptidases diversity (524,000 gene sequences; 2800 characterized enzymes, are deposited in MEROPS database; http://merops.sanger.ac.uk [7]).

Peptidases originate from 60 evolutionary lines that resulted in an extensive multifunctional group of enzymes [8]. With structures ranging from $20 \mathrm{kDa}$-single catalytic units up to $6000 \mathrm{kDa}$-agglomerates of dozens of subunits, they are capable to fragment proteins completely for recycle amino acids, as well make specific cleavages to regulate the fate and activity of many proteins, modulate protein-protein interactions, amplify molecular signals and create new bioactive molecules [9].

Indeed, at germination, these enzymes vary even in model plants. The hydrolysis routes of SSP among different plants show more similarities to the SSP cleavage sites than the peptidases that cleave then [10]. This is not expected, because SSP are conserved structures and similar protein structures tend to be cleaved by the same peptidase types [8].

Plant peptidases show direct involvement in essential cell cycles [11] [12] [13] [14]. However, few plant peptidases are well known and still less that ones used technologically, when compared to peptidases from mammalian and microorganisms. These latter are intensively studied and have generated fundamental information about biological knowledge of living beings [8], as well many uses in research, medicine, pharmacy, food and industry [15] [16] [17]. In fact, peptidases account for $60 \%$ of all commercially available enzymes [18]. 
On the other side, from works with peptidases active in germination, the majority focuses isolated enzymes. In spite of the obligatory use of purified enzymes to determine their structures, specific functions, evolutionary relations and technological applications, works that exploit germination in relation to whole proteolytic activity are rare. But it is important to expand the plant peptidases research on a diverse genetic basis to increase knowledge about proteolysis in germination, as well in other plant proteolytic processes; and to explore the technological use that plant peptidases may have [19] [20].

In this way, our objective was to carry out a scan of the proteolyticactivity during and after germination inseeds of a subtropical woody species native to South America. Woody species represent the ecological climax of most terrestrial ecosystems, but there is little biochemistry information about its germination, especially from the tropical and subtropical ones. However, A. colubrina (Fabaceae), called Angico in Brazil, has pharmacological [21]-[26], agricultural [27], anthropological [28] [29] and phytogeographic [30] importance, as well to food industry [31]. In addition, $A$. colubrina shows experimental advantages that confer model plant characteristics for studies about woody trees germination: it presents orthodox seeds with high, fast and uniform germination rate, high SSP content and ease of separating embryonic axes from cotyledons.

In this context, we used synthetic peptide substrates and peptidase inhibitors to detect, quantify and partially characterize, via spectrofluorometry and high performance liquid chromatography, the activity of peptidases in protein extracts from $A$. colubrina embryonic axis and cotyledons separated before, during and after germination.

\section{Material and Methods}

\subsection{Sample Preparation}

A. colubrina seeds were supplied by LAS/UFLA, from a batch of seeds randomly collected from several local trees $\left(21^{\circ} 14^{\prime} 42^{\prime \prime S} 45^{\circ} 00^{\prime} 00^{\prime \prime} \mathrm{W}\right)$. Visibly normal and undamaged seeds were placed to germinate on rolls made from 3 sheets of germitest paper soaked in distilled water at volume 2.5 times the dry paper weight. These seed rolls were kept at $30^{\circ} \mathrm{C}$, without photoperiod control, during $0,6,12$, 18 and 24 hours (h). Fifty seeds were used for each hydration time. Seeds apparently dead or presenting necroses were not collected. The seed coats from the remaining seeds were discarded, embryonic axes (E) and cotyledons (C) were separated and collected for immediate protein extraction. Collected tissues from $\mathrm{E}$ and $\mathrm{C}$ were macerated using liquid $\mathrm{N}_{2}$. The powder was homogenized with ice-cold Tris buffer [50 mM/pH 7.5] at $25 \mathrm{mg}$ E or $100 \mathrm{mg} \mathrm{C}$ to $1 \mathrm{~mL}$ buffer. The homogenate was maintained at $4^{\circ} \mathrm{C}$ for $2 \mathrm{~h}$ under occasional shaking and then centrifuged twice at $16,000 \mathrm{~g}$ for $20 \mathrm{~min}$ at $4^{\circ} \mathrm{C}$. The supernatant containing water-soluble proteins (crude extract) was diluted 1:1 with glycerol (v/v) and stored at $-40^{\circ} \mathrm{C}$. The protein content of these extracts was estimated by Bradford method [32]. Aliquots of $5 \mu \mathrm{L}$ were quantified in triplicate and work samples were 
diluted to $200 \mathrm{ng} \cdot \mu \mathrm{L}^{-1}$ with tris buffer $+50 \%$ glycerol. New $5 \mu \mathrm{L}$-quantifications in triplicate were done with the diluted samples. Uniform working samples in relation to protein concentration were aliquoted, cataloged according to tissue and hydration time of the seeds (E0 to E24/C0 to $\mathrm{C} 24$ ) and stored at $-40^{\circ} \mathrm{C}$.

\subsection{Proteolytic Activity Assays}

The proteolytic activity (At) in E and C samples was detected by spectrofluorometry using FRET (fluorescence resonance energy transfer) synthetic peptide substrates that emit fluorescence when hydrolyzed ${ }^{1}$. The substrates used were Abz-AIAFFSRQ-EDDnp, Abz-FRAK(Dnp)-OH, F-MCA and Z-FR-MCA. These substrates were synthesized according INFAR protocol [33]. The hydrolysis reactions were performed at $\mathrm{pH} 3$ to 9 . Each of these 280 reactions ( 10 samples $\times$ $7 \mathrm{pH}$ points $\times 4$ substrates) was run with $4 \mu \mathrm{g}$ of proteins and $5 \mu \mathrm{M}$ of substrate into $1 \mathrm{~mL}$ of $50 \mathrm{mM}$ sodium acetate buffer $(\mathrm{pH} 3 ; 4 ; 5)$, bis-tris $(\mathrm{pH} 6)$ or tris ( $\mathrm{pH} 7 ; 8 ; 9$ ). Hydrolysis of Abz-peptidyl substrates were monitored at $\lambda_{\mathrm{Ex}}=320$ $\mathrm{nm}$ and $\lambda_{\mathrm{Em}}=420 \mathrm{~nm}$; and of peptidyl-MCA substrates at $\lambda_{\mathrm{Ex}}=380 \mathrm{~nm}$ and $\lambda_{\mathrm{Em}}$ $=460 \mathrm{~nm}$. Both monitoring were done in a spectrofluorometer Hitachi F-2500 with temperature control and magnetic stirring bar in the cuvette cell. Allreactions were monitored for $10 \mathrm{~min}$ at $37^{\circ} \mathrm{C}$ and the $\mathrm{A} t$ results were expressed in $\mathrm{nM}$ of substrate hydrolyzed per $\mu \mathrm{g}$ protein per min using the Equation 1:

$$
\mathrm{A} t=\frac{V h}{K n \cdot p t} \times 1000
$$

where $\mathrm{A} t$ is proteolytic activity $\left(\mathrm{nM} \cdot \mu \mathrm{g} \cdot \mathrm{min}^{-1}\right), V h$ is hydrolysis rate $(\mathrm{AFU} / \mathrm{min})$, $K n$ is $K$ constant for each fluorescent group $(\mathrm{AFU} / \mu \mathrm{M})$ and $p t$ is the amount of protein in the sample $(\mu \mathrm{g})^{2}$. All reactions were performed in duplicate.

\subsection{Proteolytic Activity Inhibition Assays}

After obtaining A $t$ data, were chosen 6 results with Abz-AIAFFSRQ-EDDnp, 3 with Abz-FRAK(Dnp)-OH, 8 with F-MCA and 3 with Z-FR-MCA to repeat the reactions that gave rise to these 20 results, but now using peptidase inhibitors. These results were chosen due At expressivity from individual samples and/or particular variations of $\mathrm{A} t$ in time profile and/or $\mathrm{pH}$ profile. The peptidase inhibitors used were $1 \mu \mathrm{M}$ Pepstatin, $5 \mu \mathrm{M}$ E-64, $500 \mu \mathrm{M}$ PMSF or 5 mMo-phe, which are aspartyl-, cysteine-, serine- and metallo-peptidases inhibitors, respectively. The reactions were performed with protein solutions (4 $\mu \mathrm{g} \cdot \mathrm{mL}^{-1}$ ) been incubated in absence or presence of inhibitors for $10 \mathrm{~min}$ at $37^{\circ} \mathrm{C}$ under stirring. Thereafter, substrate was added and its hydrolysis was monitored for $10 \mathrm{~min}$. The results were determined by Equation (1) and converted at ${ }^{1}$ By resonance to $\mathrm{Z}, \mathrm{EDDnP}$ and Dnp quenching groups, $\mathrm{Abz}$ and MCA fluorescent groups exhibit low fluorescence that increases when the substrate molecule is ruptured.

${ }^{2}$ The spectrofluorometer was adjusted to record the fluorescence every $0.4 \mathrm{~s}$ during $10 \mathrm{~min}$. With increasing amount of fluorescence over time, the equipment generates an accurate linear regression $\left(\mathrm{R}^{2}>0.99\right)$, whose angular coefficient corresponds to hydrolysis speed and represents a direct measure of the proteolytic activity. 
percentage of inhibition relative to the control. The inhibitionhydrolysis of Abz-FRAK(Dnp)-OH by o-phe was performed by high performance liquid chromatography (HPLC).

\subsection{Proteolytic Activity Inhibition by HPLC Assay}

To quantify the inhibition of Abz-FRAK(Dnp)-OH hydrolysis by o-phe, proteins solutions $\left(8 \mu \mathrm{g} \cdot \mathrm{mL}^{-1}\right)$ containing or not $5 \mathrm{mM}$ o-phe were incubated at $37^{\circ} \mathrm{C}$ for $10 \mathrm{~min}$ under stirring. Thereafter, $30 \mu \mathrm{M}$ of substrate was added and aliquots $(240 \mu \mathrm{L})$ were collected at $0,7.5,15,30$ and $60 \mathrm{~min}$ (serial hydrolysis). At each collect, the reaction was immediately stopped with $10 \mu \mathrm{L}$ of trifluoroacetic acid (TFA) $1 \mathrm{M}$ and stored at $-40^{\circ} \mathrm{C}$. From these aliquots, $150 \mu \mathrm{L}$ were injected into Shimadzu chromatograph with SPD-10AV UV-Vis and RF-535 fluorescence detectors coupled to Ultrasphere C-18 column $(5 \mu \mathrm{m} / 4.6 \mathrm{~mm} \times 150$ $\mathrm{mm})$ equilibrated with solvent $[90 \%$ acetonitrile $+0.1 \%$ TFA (v/v)] at $10 \%$. Samples were solvent-eluted in $10 \%-80 \%$ gradient at $1 \mathrm{~mL} \cdot \mathrm{min}^{-1}$ for $28 \mathrm{~min}$ and the column eluates were monitoredby their absorbance at $220 \mathrm{~nm}$ and by their fluorescence emissionat $420 \mathrm{~nm}$ following excitation at $320 \mathrm{~nm}$. As chromatographic standards, were injected $150 \mu \mathrm{L}$ of: $10 \mu \mathrm{M}$ hydrolyzed substrate by sample for $15 \mathrm{~h}$ at $37^{\circ} \mathrm{C} ; 10 \mu \mathrm{M}$ non-hydrolyzed substrate; $8 \mu \mathrm{g} \cdot \mathrm{mL}^{-1}$ protein + $40 \mathrm{mM} \mathrm{TFA}$; and $8 \mu \mathrm{g} \cdot \mathrm{mL}^{-1}$ proteins $+40 \mathrm{mM} \mathrm{TFA}+5 \mathrm{mM}$ o-phe. Linear regression curves were constructed with the data of product amount from serial hydrolysis and the results were expressed as percentage inhibition relative to control without inhibitor.

\subsection{Data Analysis}

The proteolitic activity $(A t)$ is a peptidic substrate function and there is no relation between quantification data and peptidic substrate. Thus, all of the at values from the same substrate were divided by the sample value that displayed maximum A $t$ and were rented as Relative Activity $\left(\mathrm{A} r=\mathrm{A} t / \mathrm{A} t_{\max }\right)$. Peptidases class was chosen according to the inhibition percentage that each peptidases inhibitor had on tested At. Therefore, the data were also relatively expressed. After the individual analyzes with each substrate we obtained a tissue-temporal map of the proteolytic activity in A. colubrina seeds.

\section{Results}

In this work, we perform an exploratory mapping of the peptidase activity in $A$. colubrina during and after germination seeds. The experiments were performed with crude protein extracts and synthetic substrates not with isolated peptidases and purified seed storage proteins (SSP), which would allow discerning, qualifying and quantifying the activity of specific peptidases. Therefore, no clear distinction was made among peptidases with specific function in SSP hydrolysis from peptidases related to other cellular processes, in spite of the activities were detected at germination. For the same reason, no distinction was made between 
possible isoforms. Although many peptidases are common to embryonic axis(E) and cotyledons $(\mathrm{C})$, since cotyledonary tissue is embryonic tissue, there are isoenzyme members differentially present between these tissues [34]. Thus, for results discussion, the same peptidase class, detected in both $\mathrm{E}$ and $\mathrm{C}$ samples, was considered as represented by enzymes common at both tissues and that the different relative activities (Ar) between these tissues were due to different enzyme concentration in the constant protein concentration of the samples. By this way, our data allowed to discern patterns of tissue-temporal proteolytic activity in the seed submitted to germination and indicate the classes of peptidases correlated with these activities.

In addition, radicle protrusion was used as criterion for germination of the seed batch. By this criterion, $4 \%$ of the seeds germinated at $12 \mathrm{~h}, 58 \%$ at $18 \mathrm{~h}$ and $93 \%$ at $24 \mathrm{~h}$ by hydration time (data not shown). No seed germinated in $6 \mathrm{~h}$. Thus, the period up to $12 \mathrm{~h}$ refers to the beginning of the seed batch germination, $18 \mathrm{~h}$ at its end (>50\%) and $24 \mathrm{~h}$ to post-germination events. On the other side, the proteolytic activity detected at $6 \mathrm{~h}$ was intermediate between 0 and $12 \mathrm{~h}$ and that detected at $18 \mathrm{~h}$ were intermediate between 12 and $24 \mathrm{~h}$, both for $\mathrm{E}$ and $\mathrm{C}$ samples. Thus, the proteolytic data of $6 \mathrm{~h}$ and $18 \mathrm{~h}$ were not shown, being sufficient for analysis the times 0,12 and $24 \mathrm{~h}$ as representative of the proteolytic events occurred respectively before, during and after germination of $A$. colubrina seeds.

\subsection{Peptidases Detected with Abz-AIAFFSRQ-EDDnp Hydrolysis}

Using Abz-AIAFFSRQ-EDDnp, which is specific for detecting endopeptidases, maximal activities were verified at $\mathrm{pH} 3$ (Figure 1 ) and were 100\% inhibited by pepstatin at all reactions tested (Table 1). The addition of cysteine peptidases (CP) activator DTT ( $5 \mathrm{mM})$ or CPs irreversible inhibitor E-64 $(5 \mathrm{mM})$ at $\mathrm{pH} 5$ and $\mathrm{pH} 7$ did not result in activity change (Table 1). These results exclude the presence of CPs [35] and indicate that the activity observed were exclusive of aspartyl-endopeptidases (AP).

Table 1. Peptidases classes identified by Abz-AIAFFSRQ-EDDnp substrate. Peptidases class identificationn on proteic extracts from embryonary axis and cotyledons from $A$. colubrina obtained from Abz-AIAFFSRQ-EDDnp substrate clivage inhibition (\%) caused different peptidases inhibitors. Values in parentheses $=\mathrm{pH}$ reaction; null $=$ activity not altered by E-64 or DTT; (-) not tested.

\begin{tabular}{ccccc}
\hline \multirow{2}{*}{ samples } & $\begin{array}{c}\text { Inhibitor/Peptidase } \\
\text { (class) }\end{array}$ & $\begin{array}{c}\text { Inhibitor/Peptidase } \\
\text { (class) }\end{array}$ & $\begin{array}{c}\text { Inhibitor/Peptidase } \\
\text { (class) }\end{array}$ & $\begin{array}{c}\text { Inhibitor/Peptidase } \\
\text { (class) }\end{array}$ \\
\cline { 2 - 5 } & Pepstatin/Aspartyl & E-64/Cysteine & PMSF/Serine & o-phe/Metallo \\
\hline E0 & $100(3)$ & null $(5 ; 7)$ & - & - \\
E12 & $100(3 ; 4)$ & - & - & - \\
E24 & $100(3)$ & - & - & - \\
C0 & $100(3)$ & - & - & - \\
C24 & $100(3)$ & null $(5 ; 7)$ & - & - \\
\hline
\end{tabular}



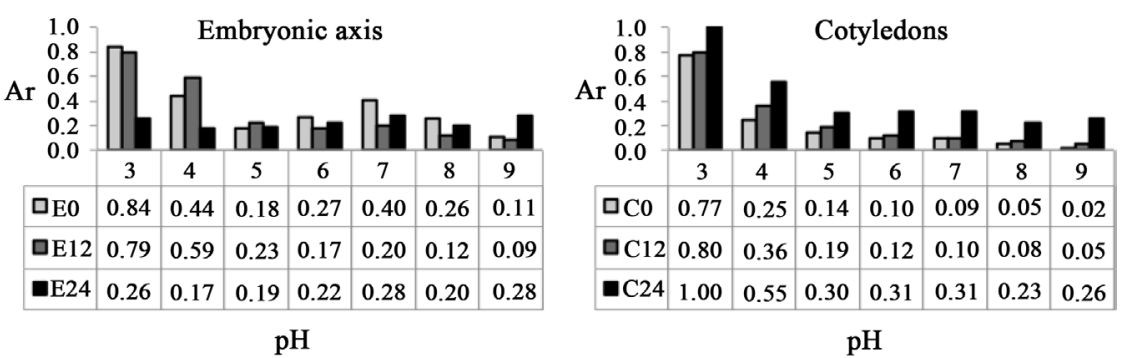

Figure 1. Relative activity (Ar) at pH 3 to 9, quantified by spectrofluorometry, as a function of Abz-AIAFFSRQ-EDDnp hydrolysis in protein extracts from A. colubrina embryonic axis and cotyledons, excised at 0, 12 and $24 \mathrm{~h}$ from seed hydration (E0, E12, E24/ $\mathrm{C} 0, \mathrm{C} 12, \mathrm{C} 24)$.

Plant aspartyl-peptidases (AP), or phytepsins, are endopeptidases specifically inhibited by pepstatin. They have maximum activity at acidic $\mathrm{pH}$ on several organic or synthetic substrates and show preference to hydrolyze peptide bonds formed by hydrophobic residues [36] [37], mainly Leu-Tyr, Phe-Tyr and Phe-Phe bonds at insulin $\beta$-chain [38]; as is the case of Phe-Phe (FF) bond present in Abz-AIAFFSRQ-EDDnp.

The temporal activity profile versus $\mathrm{pH}$ activity profile in Abz-AIAFFSRQ-EDDnp hydrolysis suggests the presence of three APs differentially expressed by the tissues (Figure 1). The first AP (AP1) is stored in both dry seed tissues, as indicated by the activities of $\mathrm{E} 0$ and $\mathrm{C} 0$ in $\mathrm{pH}$ 3. The second AP (AP2) is synthesized during germination, as indicated by the higher $\mathrm{E} 12$ or $\mathrm{C} 12$ activity on that $\mathrm{E} 0$ or $\mathrm{C} 0$ at $\mathrm{pH}$ 4. AP2 differs from AP1 by being more active at $\mathrm{pH} 4$, although both APs have maximum activity at $\mathrm{pH} 3$. The third AP (AP3) is synthesized in the cotyledons after germination, as indicated by $A t_{\max }$ at $\mathrm{C} 24 / \mathrm{pH} 3$ and by it lower and stable activity at all $\mathrm{pH}$ values at $\mathrm{C} 24$. An AP with maximum activity at $\mathrm{pH} 3.5$ and stable between $\mathrm{pH} 2$ and $\mathrm{pH} 10$ was characterized in $V$. radiata [37]. Similar pattern was described for a recombinant AP in Arabidopsis [38]. In A. colubrina there is also indicated a fourth endopeptidase $(\mathrm{E} 0 / \mathrm{pH} 7)$, whose class was not determined in this study.

These results suggest a sequential events where AP1 initiates the proteolysis in the protein bodies in embryonic axis and cotyledons, which is followed by AP2 mRNAs translation and after by AP3 mRNAs transcription and translation, mainly in cotyledons. The indication of these three APs in A. colubrina and the events sequence suggested is in accordance with the general seed pattern to store inactive forms of peptidases and their respective mRNAs during its maturation, as well to transcribe new mRNAs after germination. These suggest that peptidases and mRNAs stored in the embryos are sufficient for germination and that the largest mass of SSP is hydrolyzed from the storage tissues at post-germination events [2] [5].

In fact, APs are accumulated in protein bodies [39], hydrolyze SSP in vitro and in vivo [40] [41] [42], showing that APs should participate in SSP hydrolysis at initial germination stages, according to the criteria established by Shutov and 
Vaintraub [1], followed to date to restrict peptidases and their functions to the specific processes of SSP hydrolysis: 1) the peptidase must be localized (or transported) next to its native substrate; 2) the peptidase must hydrolyze its native substrate in vitro and; (3) the temporal patterns between peptidase activity and substrate degradation in vivo must coincide. In addition, two or more cDNAs for different APs were obtained from dry seeds and during germination in buckwheat [43], wheat [41], soybean [44] and Arabidopsis [45], as well as aspartyl activity was observed during seed germination in Araucaria megagametophyte [46].

\subsection{Peptidases Detected with Abz-FRAK(Dnp)-OH Hydrolysis}

The hydrolysis of Abz-FRAK(Dnp)-OH, which was designed for detect carboxypeptidase activities, shown that the activity increased with time in both tissues, but in different $\mathrm{pH}$ profiles (Figure 2). This suggests the presence of different peptidases stored and synthesized during and after germination in each tissue. According the results, these peptidases belongs to the classes of AP, CP and metallo-peptidases (MP), at embryonic axis; and to CP and MP classes at cotyledon, as indicated by the inhibitors effectiveness (Table 2 and Table 3 ).

The indication of AP and CP presences were respectively based on the relative spectrofluorometric quantification of Abz released during Abz-FRAK(Dnp)-OH hydrolysis from samples pre-incubated with pepstatin or E-64 (Table 2). By the other side, the indication of MP presence was based on the relative chromatographic
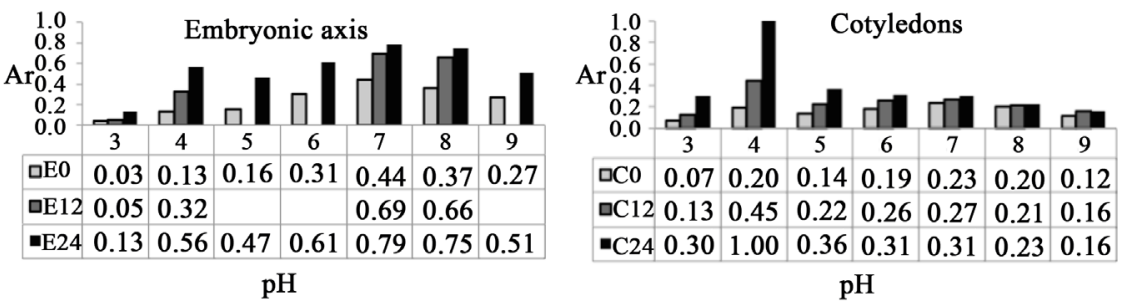

Figure 2. Relative activity (Ar) at pH 3 to 9 , quantified by spectrofluorometry, as a function of Abz-FRAK(Dnp)-OH hydrolysis, in protein extracts from $A$. colubrina embryonic axis and cotyledons, excised at 0, 12 and $24 \mathrm{~h}$ from seed hydration (E0, E12, E24/C0, C12, C24).

Table 2. Peptidases classes identified by Abz-FRAK(Dnp)-OH substrate. Peptidases class identification on proteic extracts from embryonary axis and cotyledons from A. colubrina obtained from Abz-FRAK(Dnp)-OH substrate clivage inhibition (\%) caused different peptidases inhibitors. Values in parentheses $=\mathrm{pH}$ reaction; null $=$ activity not altered by E-64 or DTT; (-) not tested.

\begin{tabular}{ccccc}
\hline \multirow{2}{*}{ Samples } & $\begin{array}{c}\text { Inhibitor/Peptidase } \\
\text { (class) }\end{array}$ & $\begin{array}{c}\text { Inhibitor/Peptidase } \\
\text { (class) }\end{array}$ & $\begin{array}{c}\text { Inhibitor/Peptidase } \\
\text { (class) }\end{array}$ & $\begin{array}{c}\text { Inhibitor/Peptidase } \\
\text { (class) }\end{array}$ \\
\cline { 2 - 5 } & Pepstatin/Aspartyl & E-64/Cysteine & PMSF/Serine & o-phe/Metallo \\
\hline E24 & $36(4)$ & $57(4) ; 3^{n r}(7)$ & $1^{n r}(7)$ & HPLC $(4 ; 7)$ \\
C24 & $14^{n r}(4)$ & $87(4)$ & - & HPLC $(4)$ \\
\hline
\end{tabular}


Table 3. Abz-FRAK(Dnp)-OH hydrolyzed by samples E24/pH 4, C24/pH 4 and E24/pH 7 generated 3 fragments [R $t=11.8 ; 12.3$ and 12.7 (Figure 3)] obtained in proportional amounts to hydrolysis times $(h t=7.5,15,30,60 \mathrm{~min})$ with or without o-phe [inhibited $(i)$ and control $(c)$, respectively]. Linear regression curves were constructed with the peak area values of these quantities [angular coefficient $(\alpha)$ and $\mathrm{R}^{2}$ indicated]. The substrate hydrolysis inhibition per sample is given by $i / c$ ratio of the total quantities $(\mathrm{Q} t)$ [or relative quantities $(\mathrm{Q} r)$ ] obtained by the sum of $i$ and $c$ of all $h t$ peak values of the 3 fragments.

\begin{tabular}{|c|c|c|c|c|c|c|c|}
\hline & \multirow{2}{*}{$h t$} & \multicolumn{2}{|c|}{$\mathrm{E} 24 / \mathrm{pH} 4$} & \multicolumn{2}{|c|}{$\mathrm{C} 24 / \mathrm{pH} 4$} & \multicolumn{2}{|c|}{$\mathrm{E} 24 / \mathrm{pH} 7$} \\
\hline & & $i$ & $c$ & $i$ & $c$ & $i$ & $c$ \\
\hline \multirow[t]{5}{*}{$\mathrm{R} t 11.8$} & 7.5 & 100,188 & 274,256 & 568,197 & 964,183 & 166,120 & 407,029 \\
\hline & 15.0 & 126,810 & 326,520 & 951,756 & $1,467,040$ & 325,765 & 556,018 \\
\hline & 30.0 & 239,538 & 528,838 & $1,075,611$ & $1,969,896$ & 530,966 & 852,088 \\
\hline & 60.0 & 387,110 & 905,879 & $1,136,122$ & $2,389,160$ & 993,327 & $1,485,255$ \\
\hline & $\alpha / \mathrm{R}^{2}$ & $5601 / 0.991$ & $12,320 / 0.996$ & $8669 / 0.623$ & $25,171 / 0.896$ & $15,432 / 0.997$ & $20,559 / 0.999$ \\
\hline \multirow[t]{5}{*}{$\mathrm{R} t 12.3$} & 7.5 & 223,359 & 256,982 & 201,983 & 272,680 & 39,393 & 62,147 \\
\hline & 15.0 & 316,272 & 325,827 & 423,603 & 388,173 & 0 & 63,848 \\
\hline & 30.0 & 536,795 & 519,355 & 451,907 & 503,666 & 0 & 76,122 \\
\hline & 60.0 & 925,441 & 911,347 & 644,766 & 659,826 & 0 & 99,579 \\
\hline & $\alpha / \mathrm{R}^{2}$ & $13,447 / 0.999$ & $12,643 / 0.998$ & $7218 / 0.854$ & $6961 / 0.955$ & & $740 / 0.990$ \\
\hline \multirow[t]{8}{*}{$\mathrm{R} t 12.7$} & 7.5 & & & & & 0 & 51,812 \\
\hline & 15.0 & & & & & 0 & 68,870 \\
\hline & 30.0 & & & & & 0 & 114,616 \\
\hline & 60.0 & & & & & 0 & 200,842 \\
\hline & $\alpha / R^{2}$ & & & & & & $2872 / 0.999$ \\
\hline & $\mathrm{Q} t$ & $2,855,513$ & $4,049,004$ & $5,453,945$ & $8,614,624$ & $2,055,571$ & $4,038,226$ \\
\hline & $\mathrm{Q} r$ & 0.33 & 0.47 & 0.63 & 1 & 0.24 & 0.47 \\
\hline & Inhibition (\%) & \multicolumn{2}{|c|}{29} & \multicolumn{2}{|c|}{37} & \multicolumn{2}{|c|}{49} \\
\hline
\end{tabular}

quantification of three fragments released from this hydrolyzed substrate by samples pre-incubated with o-phe (Table 3 ). These fragments presented different retention times $(\mathrm{R} t)$ : a prominent peak $(\mathrm{R} t=11.8 \mathrm{~min})$ was observed in the three samples; a second equally prominent peak $(\mathrm{R} t=12.3 \mathrm{~min})$ in $\mathrm{E} 24 / \mathrm{pH} 4$ sample, which is greatly reduced at $\mathrm{C} 24 / \mathrm{pH} 4$ and insignificant at $\mathrm{E} 24 / \mathrm{pH} 7$; and a third little expressive peak ( $\mathrm{R} t=12.7 \mathrm{~min}$ ), observed only at $\mathrm{E} 24 / \mathrm{pH} 7$ (Figure 3).

With hydrolysis inhibition of Abz-FRAK(Dnp)-OH was observed carboxypeptidase activity of APs, CPs and MPs at acidic and neutral $\mathrm{pH}$. The detected acidic CPs activity could be related with plant cathepsin-like. Although cathepsins are usually endo-CPs from papain family, several human cathepsins have preference to Lys $(\mathrm{K})$ and $\operatorname{Arg}(\mathrm{R})$, as indicated by assays with a large substrates set [47] and human cathepsin-B has carboxypeptidase activity at acidic $\mathrm{pH}$ on Abz-FRAK(Dnp)-OH [33] [48]. In plants, homologous genes to cathepsin-B were described in wheat ( $T$. aestivum), barley ( $H$. vulgare) and Arabidopsisthaliana. In wheat [49] and barley [50], plant cathepsin-B is regulated by abscisic 

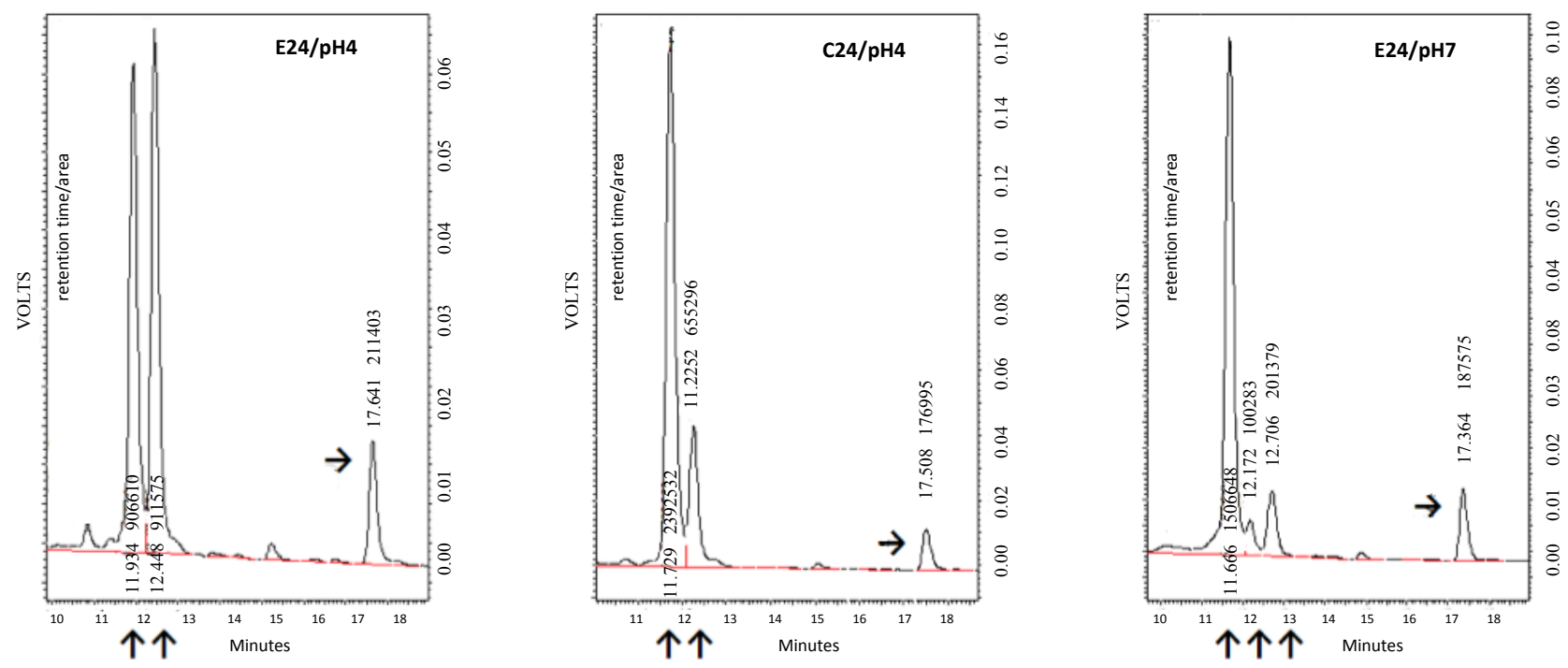

Figure 3. HPLC analysis of Abz-FRAK(Dnp)-OHhydrolyzed almost entirely by E24/pH 4, C24/pH 4 and E24/pH 7 samples showing 3 fragments that generated peaks at retention times $(\mathrm{R} t) 11.8 ; 12.3$ and $12.7 \mathrm{~min}$ approximately (vertical arrows below the graphs). Peak values $=\mathrm{R} t$ and peak area. Horizontal arrow indicates peak of non-hydrolyzed substrate.

acid (ABA) and gibberellin (GA) in aleurone layers and its expression increases with germination, as well in Arabidopsis, were a gene for cathepsin B-like, AtCathB3, is expressed at germination and post-germination events in embryonic axis and cotyledons, respectively [51]. Several plant cathepsins were discovered, among them the HvPap-1, a barley cathepsin-F [52]. Recombinant HvPap-1 degrades in vitro synthetic substrates and the native hordeins, albumins and globulins. The enzyme is immunodetected in the protein bodies (acidic environment) and the gene is expressed in isolated aleurone layers under treatment of GA. These information support the direct participation of HvPap-1 in SSP hydrolysis during germination. As it was indicated that the carboxypeptidase activity detected in $\mathrm{E} 24 / \mathrm{pH} 4$ and $\mathrm{C} 24 / \mathrm{pH} 4$ (Figure 2) can be due to CPs (Table 2), it seems possible that plant cathepsin-like participate in post-germination events in A. colubrina. However, carboxypeptidase activities of APs and MPs at acidic $\mathrm{pH}$, detected in the assays with Abz-FRAK(Dnp)-OH, are conflicting data.

According to MEROPS database [7], none carboxypeptidase belongs to APs. All known APs are restricted endopeptidases (endo-APs). However, the amino acids sequence from plant APs has $45 \%$ of homology with animal cathepsin-D (EC 3.4.23.5) [44]. Indeed, cathepsin-D is an endo-AP classified as member of A1 family (pepsin, phytepsin; MEROPS classification), which are active at acid $\mathrm{pH}$ and inhibited by pepstatin. Arabidopsis has three genes described for cathepsin D-like, one of them is expressed only in seeds [53]. APs from the pepsin family, as well as CPs from the papain family, cleave a wide variety of substrates. Abz-FRAK(Dnp)-OH was used to characterize carboxypeptidase activity at acidic $\mathrm{pH}$ of cathepsin-B of the papain family [33] [48] and AtCathB3 (cathepsin $\mathrm{B}$-like) is related to germination [51]. Thus, it seems possible that this substrate is also cleaved by some plant cathepsin-D-like from pepsin family. However, 
based on more than 800 assays deposited at the MEROPS database, it appears that human cathepsin-D has little preference to hydrolyze Abz-FRAK(Dnp)-OH, although this substrate is not included in these assays. Therefore, given the available information and our data limits, it is unreasonable to indicate the presence of a carboxy-AP in A. colubrina, but a carboxy-CP from A1 family seems to be possible.

MEROPS database [7] also revealed that plant MPs are generally endo- or amino-peptidases. No carboxy-MP has been characterized in plants. However, gene sequences relating to M14 family, which contains carboxy-MPs, has been deposited for many plant species. But MPs are characteristically neutral enzymes. Therefore, it is plausible that o-phe inhibited the activity of a possible plant carboxy-MP at E24/pH 7, but the same occurrence at E24/pH 4 and C24/pH 4 is not consistent (Table 3 ). The substrate Abz-FRAK(Dnp)-OH was used to characterize carboxy-CPs activity at acidic $\mathrm{pH}$; neverthelesscarboxy-MPs has affinity to this substrate (Prof. LuizJuliano, personal communication ). Thus, it seems possible that this substrate is cleaved by carboxy-CPs (at acidic $\mathrm{pH}$ ) and by carboxy-MPs (at neutral $\mathrm{pH}$ ). In fact, the cleavage profile of this substrate was more similar among different tissues at the same $\mathrm{pH}$, than among different $\mathrm{pH}$ in the same tissue. In Figure 3, it may be noted that $\mathrm{R} t 11.8$ and $\mathrm{R} t 12.3$ fragments are released by $\mathrm{E} 24$ and $\mathrm{C} 24$ in $\mathrm{pH} 4$, while the $\mathrm{R} t 11.8$ and $\mathrm{R} t 12.7$ fragments are released only by E24 in pH7. Furthermore, E-64 was more effective in the inhibition of $\mathrm{C} 24 / \mathrm{pH} 4$ activity than E24/pH 4 activity, but did not inhibited E24/pH 7 (Table 2), whereas o-phe inhibited E24 activity more significantly at $\mathrm{pH} 7$ than in $\mathrm{pH} 4$ (Table 3).

By the data set from Abz-FRAK(Dnp)-OH hydrolysis, it seems more plausible to suppose that, at acid $\mathrm{pH}$, o-phe inhibited not specifically the activity of some carboxy-CP (possibly a cathepsin-like) and that, at neutral $\mathrm{pH}$, specifically inhibited the activity of some carboxy-MP, not yet described in plants.

\subsection{Peptidases Detected with F-MCA Hydrolysis}

The substrate F-MCA is generally used to detect aminopeptidases and the results shown that the major activities occurred at $\mathrm{pH} 7$ (Figure 4) due to serine-peptidases (SP) and MPs (Table 4).

The temporal activity profile in $\mathrm{E}$ samples describes an increase in activity during germination, followed by decay after that, mainly at $\mathrm{pH}$ 7. By the other side, the temporal activity of $\mathrm{C}$ samples profile was constant (Figure 4). These results suggest activation of stored enzymes in $\mathrm{E}$ followed by synthesis de novo and enzyme degradation after germination, possibly due SSP stocks depletion. The uniformity of activity in $\mathrm{C}$ does not show whether a similar process has occurred.

Plant metallo-aminopeptidases (amino-MPs) are distributed into M1, M17 and M24 families [7]. This distribution is mainly based on the Arabidopsis genome sequencing. Among the amino-MPs of these families, the most likely to 
Embryonic axis

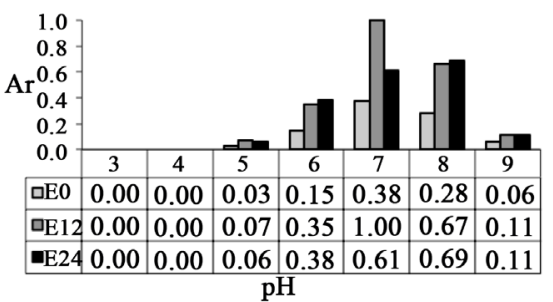

Cotyledons

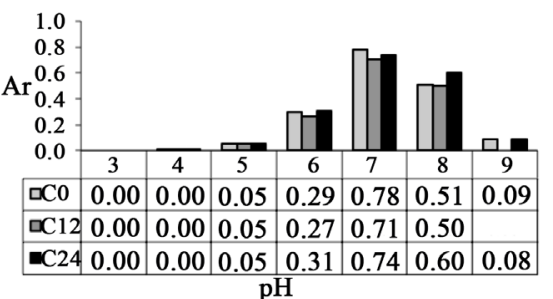

Figure 4. Relative activity (Ar) at pH 3 to 9, quantified by spectrofluorometry, as a function of F-MCA hydrolysis, in protein extracts from $A$. colubrina embryonic axis and cotyledons, excised at 0, 12 and $24 \mathrm{~h}$ from seed hydration (E0, E12, E24/C0, C12, C24).

Table 4. Peptidases classes identified by F-MCA substrate. Peptidases class identification on proteic extracts from embryonary axis and cotyledons from $A$. colubrine obtained from F-MCA substrate clivage inhibition (\%) caused different peptidases inhibitors. Values in parentheses $=\mathrm{pH}$ reaction; null $=$ activity not altered by E-64 or DTT; $(-)$ not tested.

\begin{tabular}{ccccc}
\hline \multirow{2}{*}{ Samples } & $\begin{array}{c}\text { Inhibitor/Peptidase } \\
\text { (class) }\end{array}$ & $\begin{array}{c}\text { Inhibitor/Peptidase } \\
\text { (class) }\end{array}$ & $\begin{array}{c}\text { Inhibitor/Peptidase } \\
\text { (class) }\end{array}$ & $\begin{array}{c}\text { Inhibitor/Peptidase } \\
\text { (class) }\end{array}$ \\
\cline { 2 - 5 } & Pepstatin/Aspartyl & E-64/Cysteine & PMSF/Serine & o-phe/Metallo \\
\hline E0 & - & - & $38(7)$ & $76(7)$ \\
E12 & - & - & $35(7)$ & $77(7)$ \\
E24 & - & $19^{n r}(7) ; 5^{n r}(8)$ & $47(7) ; 13^{n r}(8)$ & $74(7) ; 73(8)$ \\
C0 & - & - & $32(7)$ & $77(7)$ \\
C12 & - & - & $32(7)$ & $80(7)$ \\
C24 & - & $0(7) ; 13^{n r}(8)$ & $39(7) ; 14^{n r}(8)$ & $77(7) ; 75(8)$ \\
\hline
\end{tabular}

hydrolyze F-MCA at neutral $\mathrm{pH}$ are: leucilaminopeptidase (M17), which is related to wounds and pathogens responses and it was detected in barley [54]; and membrane alanylaminopeptidase, or aminopeptidase M1 (APM1), which hydrolyzes an inhibitor of auxin transport. Loss-of-function mutants (apml) in Arabidopsis result in uncoordinated cell divisions during embryogenesis and lethality after germination [55]. Studies with serine-aminopeptidases (amino-SP) in plants are still rarer. There were relates of a tripeptidyl-peptidase II (TPPII) purification from Arabidopsis, which hydrolyzes AAF-MCA at pH 7 and is inhibited by PMSF [56]. TPPII is an intermediate cytoplasmic exopeptidase in amino acids recycling centralized on proteasome complex [57]. It is not known if TPPII acts on the cytoplasmic phase of SSP degradation, since no direct function is attributed to proteasome on germination. However, proteasome degrades proteins that promote dormancy in Arabidopsis, allowing germination to proceed [58].

\subsection{Peptidases Detected with Z-FR-MCA Hydrolysis}

The hydrolysis of Z-FR-MCA, generally substrate for CP and SP, was more expressive in the $\mathrm{E}$ samples, in which the activity increased with time and $\mathrm{pH}$ scale (Figure 5). At all times in E samples, the activity was inhibited by o-phe, 


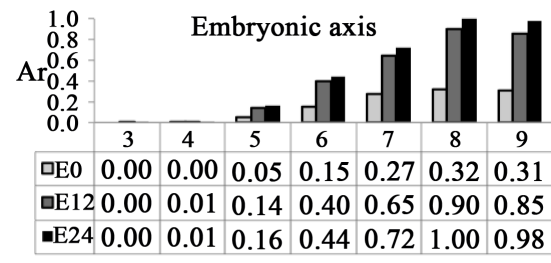

$\mathrm{pH}$

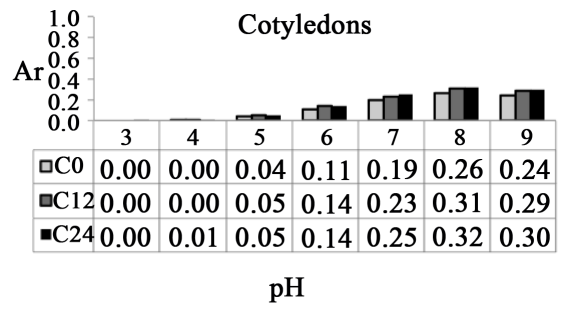

$\mathrm{pH}$

Figure 5. Relative activity (Ar) at pH 3 to 9, quantified by spectrofluorometry, as a function of Z-FR-MCA hydrolysis, in protein extracts from $A$. colubrina embryonic axis and cotyledons, excised at 0, 12 and $24 \mathrm{~h}$ from seed hydration (E0, E12, E24/C0, C12, C24).

indicating presence of MP, whereas in E24, it was also inhibited by E-64 and PMSF, indicating presence of CP and SP, respectively (Table 5). The low activity of C samples did not increase in the presence of $5 \mathrm{mM}$ DTT (data not shown), indicating that $\mathrm{CP}$ activity had already reached its maximum.

Legumains are a group of endo-CP related to storage and hydrolysis of globulins in some model plants. One of the major evidences for this is the fact that they are stored together with globulins in the acidic environment of the protein bodies [34] [59]. In fact, the maximum activity of these purified CPs occurred at acid $\mathrm{pH}$ [59] [60], including Z-FR-MCA as substrate [61]. Therefore, our results indicate that the cysteine activity detected with Z-FR-MCA in A. colubrina embryonic axis is related to another cellular process, since the maximum activity occurred in neutral-alkaline $\mathrm{pH}$ (Figure 5). The only peptidase found for this condition was the cytoplasmic phytocalpain, encoded by corn DEK-1 (Defective Kernel) and its orthologues in 11 species. This CP, associated to cell polarization, is a key enzyme in cell proliferation and differentiation during plant organogenesis, including leaf primordia [62]. According to phytocalpain function, the temporal profile of neutral-alkaline $\mathrm{CP}$ activity in the embryonic axis, as well as the possible presence of these enzymes in lower concentration in cotyledons, suggests a process of seedling development.

Due to the low proteolytic activities in $\mathrm{C}$ samples (Figure 5), the cysteine, serine and metallo activities were not tested. However, it is assumed that this low activity is due to lower concentrations of the same peptidases detected at high concentration in $\mathrm{E}$ after germination - which makes it strange that neutral-alkaline activity of $\mathrm{CP}$, as well as SP and MP, is low in A. colubrina cotyledons. Although there are CPs, such as bean LLP [63] and soybean C2 protease [64], which are detected around 5 days after hydration, there are also SPs, such as soybean protease C1 [65] and several CP of Vicia sativa [34], that are stored in protein bodies from embryonic axis and cotyledon, which are activated by hydration. On the other hand, neutral-alkaline amino-MP with preference for Phe or Leuare associated with the final globulin hydrolysis. Acidic endo- and carboxy-peptidases release oligopeptides that are diffused from protein bodies into cytoplasm, where they are finally cleaved by neutral-alkaline SP and MP [1]. Considering that this final phase of SSP hydrolysis must be intense in protein storage tissues, it is possible that metallo activity would increase after $24 \mathrm{~h}$ in 
Table 5. Peptidases classes identified by Z-FR-MCA substrate. Peptidases class identification on proteic extracts from embryonary axis and cotyledons from $A$. colubrine obtained from Z-FR-MCA substrate clivage inhibition (\%) caused different peptidases inhibitors. Values in parentheses $=\mathrm{pH}$ reaction; null $=$ activity not altered by E-64 or DTT; $(-)$ not tested.

\begin{tabular}{ccccc}
\hline \multirow{2}{*}{ Samples } & $\begin{array}{c}\text { Inhibitor/Peptidase } \\
\text { (class) }\end{array}$ & $\begin{array}{c}\text { Inhibitor/Peptidase } \\
\text { (class) }\end{array}$ & $\begin{array}{c}\text { Inhibitor/Peptidase } \\
\text { (class) }\end{array}$ & $\begin{array}{c}\text { Inhibitor/Peptidase } \\
\text { (class) }\end{array}$ \\
\cline { 2 - 5 } & Pepstatin/Aspartyl & E-64/Cysteine & PMSF/Serine & o-phe/Metallo \\
\hline E0 & - & $23^{n r}(8)$ & $8^{n r}(8)$ & $52(8)$ \\
E12 & - & $21^{n r}(8)$ & $14^{n r}(8)$ & $56(8)$ \\
E24 & - & $52(8)$ & $56(8)$ & $52(8)$ \\
\hline
\end{tabular}

A. colubrina cotyledons. Another possibility to explain this tissue-temporal profile of neutral-alkaline MP in A. colubrina takes place by the action of plant matrix metallo-peptidases (MMP). MMP are cytoplasmic endo-MP associated with cell membrane remodeling in developmental and/or wound processes [66]. The temporal stability of the metallo activity in the Z-FR-MCA hydrolysis by E samples (Table 5) suggests proteolytic activity associated with constant remodeling of membranes in developing tissues and not activity associated with SSP hydrolysis, which is expected to increase with the germination, especially in cotyledons. However, it seems that MMP has no preference for Phe or Arg [8].

Among plant SP, a reasonable assumption is the trypsin-like plant oligopeptidase-B (SC clan, S9 family, MEROPS classification). This enzyme is expressed in quiescent and germinating embryos of wheat and cleaved Z-FR-MCA with maximum activity at $\mathrm{pH} 8.5$ [67]. Their role in plants and their native substrate is not known, but due to their cleavage specificities and inefficiency against some protein substrates, Tsuji et al. [67] discuss their role in the cytoplasmic protein turn-over and not in the SSP final hydrolysis. A similar result was observed in Canavalia ensiformis. A SP purified from seeds showed high preference for Arg (Z-RR-MCA) at $\mathrm{pH} 8$ and poor efficiency against the native concavaline [68]. Although the final stages of SSP degradation occur in the cytoplasm by neutral peptidases, which do not recognize the unmodified native protein present in the acidic environment of the protein bodies [1], the indication of the plant oligopeptidase-B does not participate in SSP hydrolysis [67] is consistent with the low proteolytic activity in A. colubrina cotyledons on Z-FR-MCA hydrolysis (Figure 5), considering that the SP detected in the embryonic axis is also present in cotyledons, although at low concentrations.

\section{Discussion}

Using fluorescent peptides and peptidase inhibitors, we detected several proteolytic activities associated with aspartyl-, cysteine-, metallo- and serine-peptidases (AP, CP, MP and SP, respectively) in protein extracts from $A$. colubrina embryonic axis (E) and cotyledons (C) excised before, during and after germination. The experimental conditions do not allow to directly relating the observed 
activities in $\mathrm{E}$ and $\mathrm{C}$ samples with specific germination events, since they do not allow discerning isolated peptidases, specific functions or native substrates. However, it was possible to make inferences about the possible peptidase identity related to the activities detected. These inferences were made from the determination of the catalytic class (based on $\mathrm{pH}$ of enzymatic activity, substrates used and peptidase inhibitors effectiveness) and from the tissue-temporal profile of seed proteolytic activity.

Considering experimental conditions, we speculate that phytepsins (AP group) initiate the SSP hydrolysis in $A$. colubrina. In cultivated dicots, the most common enzymes in SSP hydrolysis are CPs. Legumains and other CPs are involved in reserve globulin processing during seed maturation and its hydrolysis within the acidic protein bodies during germination [59] [63]. The substrate Abz-AIAFFSRQ-EDDnp was designed to specifically detect endo-CPs (Dr. LuizJuliano, personal communication), but acidic endo-CPs were not detected. Only AP activity at acidic $\mathrm{pH}$ was observed in $A$. colubrina using this substrate. By the other side, legumains are not able to cleave Abz-AIAFFSRQ-EDDnp, since they has restricted specificity in vitro to cleave substrates with Asn $(\mathrm{N})$ at P1 position ${ }^{3}$ [69]. Nevertheless, no activity at acid $\mathrm{pH}$ was detected using Abz-KLNSSKQ-EDDnp as substrate (data not shown).

Although non-detection of CPsusing these substrates does not exclude the possibility of CPs presence in A. colubrina seeds, phytepsins have been directly associated with SSP hydrolysis, by their presence in protein bodies [39], and ability to hydrolyze in vitro native substrates from peanut (Arachis hypogaea L.) [42] and wheat (Dunaevsky et al. 1989; [41] [70]). Phytepsins were also indirectly associated with germination in soy [44], buckwheat [43], Arabidopsis [45], wheat [41] and Araucaria [46].

However, Shutov and Vaintraub [1] consider that protein bodies has $\mathrm{pH} 4-5$ and globulins, at $\mathrm{pH} 3$, undergo conformational changes that would expose cleavage sites toAPs, which explain their participation in the SSP hydrolysis, but not to trigger the process, likewise CPs. In fact, the APs temporal activity profile in $A$. colubrina embryonic axis is different between $\mathrm{pH} 3$ and $\mathrm{pH} 4$. However, a MP initiate the legumin hydrolysis in buckwheat (Fagopyrum esculentum) [71], which indicates that native globulins can be cleaved by more than one class of peptidases. Anyway, the temporal activity of endo-APs in A. colubrina it is in agreement with the fact that embryonic axis readily consume its reserves by the activity of peptidases stored during seed maturation and synthesized during germination, while cotyledons increase peptidases synthesis mainly after germination, in order to increase the amino acids supply to the growing seedling. Thus, regardless of phase or possible presence of CPs, phytepsins may participate in A. colubrina SSP hydrolysis.

In the case of carboxy-MP activity detected by the hydrolysis of Abz-FRAK(Dnp)-OH, it was not possible to suppose some specific enzyme, ${ }^{3} \mathrm{P} 1$ refers to the $1^{\text {st }}$ residue of sessile bond in the substrate accommodated by the $1^{\text {st }}$ residue of enzyme catalytic site at $\mathrm{N}$-terminal orientation. 
since carboxy-MP is not described in plants, although gene sequences for several plant species are deposited in MEROPS databank. Carboxypeptidases that act with endo-CP in the globulin hydrolysis are SP (carboxy-SP) [1]. In fact, carboxy-SP were confirmed in the germination of wheat [70] and triticale [72] (Drzymała and Bielawski 2009). However, we detected expressive carboxy-CP activity at acidic $\mathrm{pH}$ by Abz-FRAK(Dnp)-OH hydrolysis, mainly in cotyledons; and carboxy-CP (plant cathepsin-like) are described in wheat aleurone [49] (Cejudo et al. 1992), barley [50] (Martinez et al. 2003) and germinative and post-germinative events in Arabidopsis [51] (Iglesias-Fernández et al. 2014). Therefore, it is possible that some plant cathepsin-like is the carboxypeptidase that acts together with phytepsins in $A$. colubrina SSP hydrolysis. Considering the acidic activities of endo-AP and carboxy- $\mathrm{CP}$, detected after germination at higher levels in cotyledons than the axis, both enzymes should act sequentially in the protein bodies and would be responsible for the SSP hydrolysis in $A$. colubrina.

In general, these information agrees with the observations of Tan-Wilson and Wilson [10] where the pathway of SSP hydrolysis in different plants present more similarities about cleavage sites than peptidases that cleaves them. Due evolutionary implications, it considers that there should be caution with generalizations about proteolytic mechanism of SSP made from models formulated on basis in few long-cultivated species and, therefore, studies should be expanded to wild species [10]. Similar considerations were made by Bewley and Black [73], which consider the regulatory mechanisms of germination a reflex from the biological diversity.

On the other hand, none of neutral-alkaline peptidases detected appear to be involved in cytoplasmic phase of SSP final degradation in A. colubrina. Cytoplasmic amino- and di-peptidases from metallo and serine classes are involved in final degradation of the oligopeptides generated by acidic endo- and carboxy-peptidases activities within protein bodies [1]. Although amino-MP and amino-SP activities were detected with F-MCA, the tissue-temporal profile of these activities and literature informations, indicated as supposed enzymes those related with meiotic prophase (metallo APM1 [55]) or with protein turn-over (serine TPPII [56]). Likewise, the alkaline CPs, MPs and SPs activities detected with Z-FR-MCA are indicative of the presence of phytocalpain, MMP and oligopeptidase- $\mathrm{B}$, which are related with developmental processes, in general.

\section{Considerations}

We generated initial information about the proteolytic activity in $A$. colubrina germinating seeds. Our results showed that $A$. colubrina germination presents different peptidases from that commonly found in cultivated leguminous. In addition, we possibly detected a peptidase with useful characteristics for industrial purposes and another one not yet described in plants. This study reinforces the need to amplify the detection of plant peptidases on a diverse genetic basis, since 
the research focused on commercial species is a limiting factor for the knowledge of proteolysis in germination, as in other proteolytic processes in the plant kingdom, and the potential technological use of plant peptidases. In this context, the scanning method chosen for this study can be applied in comparative studies of germination between different species and in other biological processes aiming wide detection of peptidases.

\section{Acknowledgements}

Coordenação de Aperfeiçoamento de Pessoal de Nível Superior (Capes), Universidade Federal de Lavras (UFLA), Instituto Nacional de Farmacologia (INFAR), Universidade Federal de São Paulo (UNIFESP).

\section{Conflict of Interest}

The authors declare that they have no conflict of interest.

\section{References}

[1] Shutov, A.D. and Vaintraub, I.A. (1987) Degradation of Storage Proteins in Germinating Seeds. Phytochem, 26, 1557-1566. https://doi.org/10.1016/S0031-9422(00)82245-1

[2] Bewley, J.D. (1997) Seed Germination and Dormancy. Plant Cell, 9, 1055-1066. https://doi.org/10.1105/tpc.9.7.1055

[3] Rajjou, L., Gallardo, K., Debeaujon, I., Vandekerckhove, J., Job, C. and Job, D. (2004) The Effect of Alpha-Amanitin on the Arabidopsis Seed Proteome Highlights the Distinct Roles of Stored and Neosynthesized mRNAs during Germination. Plant Physiology, 134, 1598-1613. https://doi.org/10.1104/pp.103.036293

[4] Angelovici, R., Galili, G., Fernie, A. and Fait, A. (2010) Seed Desiccation: A Bridge between Maturation and Germination. Trends in Plant Science, 15, 211-218. https://doi.org/10.1016/j.tplants.2010.01.003

[5] Nonogaki, H., Bassel, G.W. and Bewley, J.D. (2010) Germination: Still a Mystery. Plant Science, 179, 574-581. https://doi.org/10.1016/j.plantsci.2010.02.010

[6] Forzza, R.C., Baumgratz, J.F.A., Costa, A., et al. (2010) As angiospermas do Brasil. Inst Pesqui do Jard Botânico do Rio Janeiro, 78-89.

[7] Rawlings, N.D., Barrett, A.J. and Finn, R. (2016) Twenty Years of the MEROPS Database of Proteolytic Enzymes, Their Substrates and Inhibitors. Nucleic Acids Research, 44, 343-350. https://doi.org/10.1093/nar/gkv1118

[8] Barrett, A., Rawlings, N. and Woessner, J. (2004) Handbook of Proteolytic Enzymes. Elsevier Academic Press, San Diego.

[9] López-Otín, C. and Bond, J.S. (2008) Proteases: Multifunctional Enzymes in Life and Disease. The Journal of Biological Chemistry, 283, 30433-30437. https://doi.org/10.1074/jbc.R800035200

[10] Tan-Wilson, A.L. and Wilson, K.A. (2012) Mobilization of Seed Protein Reserves. Physiologia Plantarum, 145, 140-153. https://doi.org/10.1111/j.1399-3054.2011.01535.x

[11] Hellmann, H. and Estelle, M. (2002) Plant Development: Regulation by Protein Degradation. Science, 297, 793-797. https://doi.org/10.1126/science.1072831

[12] Schaller, A. (2004) A Cut above the Rest: The Regulatory Function of Plant Proteas- 
es. Planta, 220, 183-197. https://doi.org/10.1007/s00425-004-1407-2

[13] van der Hoorn, R.A.L. (2008) Plant Proteases: From Phenotypes to Molecular Mechanisms. Annual Review of Plant Biology, 59, 191-223. https://doi.org/10.1146/annurev.arplant.59.032607.092835

[14] Morris, K., Linkies, A., Müller, K., et al. (2011) Regulation of Seed Germination in the Close Arabidopsis Relative Lepidium sativum: A Global Tissue-Specific Transcript Analysis. Plant Physiology, 155, 1851-1870. https://doi.org/10.1104/pp.110.169706

[15] Li, Q., Yi, L., Marek, P. and Iverson, B.L. (2013) Commercial Proteases: Present and Future. FEBS Letters, 587, 1155-1163. https://doi.org/10.1016/j.febslet.2012.12.019

[16] Tavano, O.L. (2013) Protein Hydrolysis Using Proteases: An Important Tool for Food Biotechnology. Journal of Molecular Catalysis B: Enzymatic, 90, 1-11. https://doi.org/10.1016/j.molcatb.2013.01.011

[17] Souza, P.M., Bittencourt, M.L.A., Caprara, C.C., et al. (2015) A Biotechnology Perspective of Fungal Proteases. Brazilian Journal of Microbiology, 46, 337-346. https://doi.org/10.1590/S1517-838246220140359

[18] Feijoo-Siota, L. and Villa, T.G. (2010) Native and Biotechnologically Engineered Plant Proteases with Industrial Applications. Food and Bioprocess Technology, 4, 1066-1088. https://doi.org/10.1007/s11947-010-0431-4

[19] Salas, C.E., Gomes, M.T.R., Hernandez, M. and Lopes, M.T.P. (2008) Plant Cysteine Proteinases: Evaluation of the Pharmacological Activity. Phytochemistry, 69, 2263-2269. https://doi.org/10.1016/j.phytochem.2008.05.016

[20] González-Rábade, N., Badillo-Corona, J.A., Aranda-Barradas, J.S. and Oliver-Salvador, M.D.C. (2011) Production of Plant Proteases in Vivo and in Vitro-A Review. Biotechnology Advances, 29, 983-996. https://doi.org/10.1016/j.biotechadv.2011.08.017

[21] Gutierrez-Lugo, M.T., Deschamps, J.D., Holman, T.R., Suarez, E. and Timmermann, B.N. (2004) Lipoxygenase Inhibition by Anadanthoflavone, a New Flavonoid from the Aerial Parts of Anadenanthera colubrina. Planta Medica, 70, 263-265. https://doi.org/10.1055/s-2004-818920

[22] Moretão, M.P., Zampronio, A.R., Gorin, P.J., et al. (2004) Induction of Secretory and Tumoricidal Activities in Peritoneal Macrophages Activated by an Acidic Heteropolysaccharide (ARAGAL) from the Gum of Anadenanthera colubrina (Angico Branco). Immunology Letters, 93, 189-197. https://doi.org/10.1016/j.imlet.2004.03.021

[23] Santos, J.S., Marinho, R.R., Ekundi-Valentim, E., et al. (2013) Beneficial Effects of Anadenanthera colubrina (Vell.) Brenan Extract on the Inflammatory and Nociceptive Responses in Rodent Models. Journal of Ethnopharmacology, 148, 218-222. https://doi.org/10.1016/j.jep.2013.04.012

[24] Lima, R.D.F., Alves, É.P., Rosalen, P.L., et al. (2014) Antimicrobial and Antiproliferative Potential of Anadenanthera colubrina (Vell.) Brenan. Evidence-Based Complementary and Alternative Medicine, 2014, Article ID: 802696.

[25] Pessoa, W.S., Estevão, L.R.M., Simões, R.S., et al. (2015) Fibrogenesis and Epithelial Coating of Skin Wounds in Rats Treated with Angico Extract (Anadenanthera colubrina var. cebil). Acta Cirurgica Brasileira, 30, 353-358.

https://doi.org/10.1590/S0102-865020150050000007

[26] Barreto, H.M., Coelho, K.M., Ferreira, J.H., et al. (2016) Enhancement of the Antibiotic Activity of Aminoglycosides by Extracts from Anadenanthera colubrine (Vell.) Brenan var. Cebil against Multi-Drug Resistant Bacteria. Natural Product Research, 30, 1289-1292. https://doi.org/10.1080/14786419.2015.1049177 
[27] Campos, V.A., Perina, F.J., Alves, E., et al. (2014) Anadenanthera colubrina (Vell.) Brenan Produces Steroidal Substances That Are Active against Alternaria alternata (Fr.) Keissler and That May Bind to Oxysterol-Binding Proteins. Pest Management Science, 70, 1815-1822. https://doi.org/10.1002/ps.3722

[28] Smet, P.A.G.M. and Rivier, L. (1987) Intoxicating Paricá Seeds of the Brazilian Maué Indians. Economic Botany, 41, 12-16. https://doi.org/10.1007/BF02859338

[29] Pagán-Jiménez, J.R. and Carlson, L.A. (2014) Recent Archaeobotanical Findings of the Hallucinogenic Snuff Cojoba (Anadenathera peregrina (L.) SPEG.) in Precolonial Puerto Rico. Latin American Antiquity, 25, 101-116. https://doi.org/10.7183/1045-6635.25.1.101

[30] Barrandeguy, M.E., García, M.V., Prinz, K., et al. (2014) Genetic Structure of Disjunct Argentinean Populations of the Subtropical Tree Anadenanthera colubrina var. cebil (Fabaceae). Plant Systematics and Evolution, 300, 1693-1705. https://doi.org/10.1007/s00606-014-0995-y

[31] Silva, L.C.N., Silva Júnior, C.A., Souza, R.M., et al. (2011) Comparative Analysis of the Antioxidant and DNA Protection Capacities of Anadenanthera colubrina, Libidibia ferrea and Pityrocarpa moniliformis Fruits. Food and Chemical Toxicology, 49, 2222-2228. https://doi.org/10.1016/j.fct.2011.06.019

[32] Bradford, M.M. (1976) A Rapid and Sensitive Method for the Quantitation of Microgram Quantities of Protein Utilizing the Principles of Protein-Dye Biding. Analytical Biochemistry, 72, 248-254. https://doi.org/10.1016/0003-2697(76)90527-3

[33] Judice, W.A.S., Puzer, L., Cotrin, S.S., et al. (2004) Carboxydipeptidase Activities of Recombinant Cysteine Peptidases. European Journal of Biochemistry, 271, 1046-1053. https://doi.org/10.1111/j.1432-1033.2004.04008.x

[34] Fischer, J., Becker, C., Hillmer, S., et al. (2000) The Families of Papain- and Legumain-Like Cysteine Proteinases from Embryonic Axes and Cotyledons of Vicia Seeds: Developmental Patterns, Intracellular Localization and Functions in Globulin Proteolysis. Plant Molecular Biology, 43, 83-101. https://doi.org/10.1023/A:1006456615373

[35] Callis, J. (1995) Regulation of Protein Degradation. Plant Cell, 7, 845-857. https://doi.org/10.1105/tpc.7.7.845

[36] Simões, I. and Faro, C. (2004) Structure and Function of Plant Aspartic Proteinases. European Journal of Biochemistry, 271, 2067-2075. https://doi.org/10.1111/j.1432-1033.2004.04136.x

[37] Kulkarni, A. and Rao, M. (2007) Biochemical Characterization of an Aspartic Protease from Vigna radiata: Kinetic Interactions with the Classical Inhibitor Pepstatin Implicating a Tight Binding Mechanism. Biochimica et Biophysica Acta, 1774, 619-627. https://doi.org/10.1016/j.bbapap.2007.03.014

[38] Mazorra-Manzano, M.A., Tanaka, T., Dee, D.R. and Yada, R.Y. (2010) Structure-Function Characterization of the Recombinant Aspartic Proteinase A1 from Arabidopsis thaliana. Phytochemistry, 71, 515-523.

https://doi.org/10.1016/j.phytochem.2009.12.005

[39] Hiraiwa, N., Kondo, M., Nishimura, M. and HaraNishimura, I. (1997) An Aspartic Endopeptidase Is Involved in the Breakdown of Propeptides of Storage Proteins in Protein-Storage Vacuoles of Plants. European Journal of Biochemistry, 246, 133-141. https://doi.org/10.1111/j.1432-1033.1997.00133.x

[40] Belozersky, M.A., Sarbakanova, S.T. and Dunaevsky, Y.E. (1989) Aspartic Proteinase from Wheat Seeds: Isolation, Properties and Action on Gliadin. Planta, 177, 321-326. https://doi.org/10.1007/BF00403589 
[41] Tamura, T., Terauchi, K., Kiyosaki, T., et al. (2007) Differential Expression of Wheat Aspartic Proteinases, WAP1 and WAP2, in Germinating and Maturing Seeds. Journal of Plant Physiology, 164, 470-477. https://doi.org/10.1016/j.jplph.2006.02.009

[42] Wilson, K.A. and Tan-Wilson, A. (2015) Proteolysis of the Peanut Allergen Ara h 1 by an Endogenous Aspartic Protease. Plant Physiology and Biochemistry, 96, 301-310. https://doi.org/10.1016/j.plaphy.2015.08.008

[43] Milisavljevic, M.D., Timotijevic, G.S., Radovic, S.R., et al. (2008) Two Types of Aspartic Proteinases from Buckwheat Seed-Gene Structure and Expression Analysis. Journal of Plant Physiology, 165, 983-990. https://doi.org/10.1016/j.jplph.2007.03.016

[44] Terauchi, K., Asakura, T., Nishizawa, N.K., et al. (2004) Characterization of the Genes for Two Soybean Aspartic Proteinases and Analysis of Their Different Tissue-Dependent Expression. Planta, 218, 947-957.

https://doi.org/10.1007/s00425-003-1179-0

[45] Chen, X., Pfeil, J.E. and Gal, S. (2002) The Three Typical Aspartic Proteinase Genes of Arabidopsis thaliana Are Differentially Expressed. European Journal of Biochemistry, 269, 4675-4684. https://doi.org/10.1046/j.1432-1033.2002.03168.x

[46] Capocchi, A., Muccilli, V., Casani, S., et al. (2011) Proteolytic Enzymes in Storage Protein Mobilization and Cell Death of the Megagametophyte of Araucaria bidwillii Hook Post-Germinated Seeds. Planta, 233, 817-830. https://doi.org/10.1007/s00425-010-1342-3

[47] Choe, Y., Leonetti, F., Greenbaum, D.C., et al. (2006) Substrate Profiling of Cysteine Proteases Using a Combinatorial Peptide Library Identifies Functionally Unique Specificities. The Journal of Biological Chemistry, 281, 12824-12832. https://doi.org/10.1074/jbc.M513331200

[48] Lanfranco, M.F., Loayza-Muro, R., Clark, D., et al. (2008) Expression and Substrate Specificity of a Recombinant Cysteine Proteinase B of Leishmania braziliensis. Molecular and Biochemical Parasitology, 161, 91-100. https://doi.org/10.1016/j.molbiopara.2008.06.005

[49] Cejudo, F.J., Murphy, G., Chinoy, C. and Baulcombe, D.C. (1992) A Gibberellin-Regulated Gene from Wheat with Sequence Homology to Cathepsin B of Mammalian Cells. The Plant Journal, 2, 937-948.

[50] Martinez, M., Rubio-Somoza, I., Carbonero, P. and Diaz, I. (2003) A Cathepsin B-Like Cysteine Protease Gene from Hordeum vulgare (gene CatB), Induced by GA in Aleurone Cells Is under Circadian Control in Leaves. Journal of Experimental Botany, 54, 951-959. https://doi.org/10.1093/jxb/erg099

[51] Iglesias-Fernández, R., Wozny, D., Iriondo-de Hond, M., et al. (2014) The AtCathB3 Gene, Encoding a Cathepsin B-Like Protease, Is Expressed during Germination of Arabidopsis thaliana and Transcriptionally Repressed by the Basic Leucine Zipper Protein GBF1. Journal of Experimental Botany, 65, 2009-2021. https://doi.org/10.1093/jxb/eru055

[52] Cambra, I., Martinez, M., Dáder, B., et al. (2012) A Cathepsin F-Like Peptidase Involved in Barley Grain Protein Methylation and Chromatin Patterning Mobilization, HvPap-1, Is Modulated by Its Own Propeptide and by Cystatins. Journal of Experimental Botany, 63, 4615-4629. https://doi.org/10.1093/jxb/ers137

[53] Beers, E.P., Jones, A.M. and Dickerman, A.W. (2004) The S8 Serine, C1A Cysteine and A1 Aspartic Protease Families in Arabidopsis. Phytochemistry, 65, 43-58. https://doi.org/10.1016/j.phytochem.2003.09.005 
[54] Oszywa, B., Makowski, M. and Pawełczak, M. (2013) Purification and Partial Characterization of Aminopeptidase from Barley (Hordeum vulgare L.) Seeds. Plant Physiology and Biochemistry, 65, 75-80. https://doi.org/10.1016/j.plaphy.2013.01.014

[55] Peer, W.A., Hosein, F.N., Bandyopadhyay, A., et al. (2009) Mutation of the Membrane-Associated M1 Protease APM1 Results in Distinct Embryonic and Seedling Developmental Defects in Arabidopsis. Plant Cell, 21, 1693-1721. https://doi.org/10.1105/tpc.108.059634

[56] Book, A.J., Yang, P., Scalf, M., et al. (2005) Tripeptidyl Peptidase II: An Oligomeric Protease Complex from Arabidopsis. Plant Physiology, 138, 1046-1057. https://doi.org/10.1104/pp.104.057406

[57] Preta, G., Klark, R., Gavioli, R. and Glas, R. (2010) The Enigma of Tripeptidyl-Peptidase II: Dual Roles in Housekeeping and Stress. Journal of Oncology, 2010, Article ID: 128478. https://doi.org/10.1155/2010/128478

[58] Chiu, R.S., Pan, S., Zhao, R. and Gazzarrini, S. (2016) ABA-Dependent Inhibition of the Ubiquitin Proteasome System during Germination at High Temperature in Arabidopsis. The Plant Journal, 88, 749-761. https://doi.org/10.1111/tpj.13293

[59] Schlereth, A., Standhardt, D., Mock, H. and Mu, K. (2001) Stored Cysteine Proteinases Start Globulin Mobilization in Protein Bodies of Embryonic Axes and Cotyledons during Vetch (Vicia sativa L.) Seed Germination. Planta, 212, 718-727. https://doi.org/10.1007/s004250000436

[60] Qi, X., Wilson, K.A. and Tan-wilson, A.L. (1992) Characterization of the Major Protease Involved in the Soybean B-Conglycinin Storage Protein Mobilization. Plant Physiology, 99, 725-733. https://doi.org/10.1104/pp.99.2.725

[61] Sutoh, K., Kato, H. and Minamikawa, T. (1999) Identification and Possible Roles of Three Types of Endopeptidase from Germinated Wheat Seeds. The Journal of Biochemistry, 126, 700-707. https://doi.org/10.1093/oxfordjournals.jbchem.a022506

[62] Johnson, K.L., Faulkner, C., Jeffree, C.E. and Ingram, G.C. (2008) The Phytocalpain Defective Kernel 1 Is a Novel Arabidopsis Growth Regulator Whose Activity Is Regulated by Proteolytic Processing. Plant Cell, 20, 2619-2630. https://doi.org/10.1105/tpc.108.059964

[63] Müntz, K., Belozersky, M.A., Dunaevsky, Y.E., et al. (2001) Stored Proteinases and the Initiation of Storage Protein Mobilization in Seeds during Germination and Seedling Growth. Journal of Experimental Botany, 52, 1741-1752. https://doi.org/10.1093/jexbot/52.362.1741

[64] Seo, S., Tan-Wilson, A. and Wilson, K.A. (2001) Protease C2, a Cysteine Endopeptidase Involved in the Continuing Mobilization of Soybean b-Conglycinin Seed Proteins. Biochimica et Biophysica Acta, 1545, 192-206. https://doi.org/10.1016/S0167-4838(00)00277-6

[65] He, F., Huang, F., Wilson, K.A. and Tan-Wilson, A. (2007) Protein Storage Vacuole Acidification as a Control of Storage Protein Mobilization in Soybeans. Journal of Experimental Botany, 58, 1059-1070. https://doi.org/10.1093/jxb/erl267

[66] Maidment, J.M., Moore, D., Murphy, G.P., et al. (1999) Matrix Metalloproteinase Homologues from Arabidopsis thaliana. The Journal of Biological Chemistry, 274, 34706-34710. https://doi.org/10.1074/jbc.274.49.34706

[67] Tsuji, A., Yuasa, K. and Matsuda, Y. (2004) Identification of Oligopeptidase B in Higher Plants. Purification and Characterization of Oligopeptidase B from Quiescent Wheat Embryo Triticum aestivum. The Journal of Biochemistry, 136, 673-681. https://doi.org/10.1093/jb/mvh163 
[68] Demartini, D.R., Wlodawer, A. and Carlini, C.R. (2007) A Comparative Study of the Expression of Serine Proteinases in Quiescent Seeds and in Developing Canavalia ensiformis Plants. Journal of Experimental Botany, 58, 521-532. https://doi.org/10.1093/jxb/erl223

[69] Jung, R., Scott, M.P., Nam, Y., et al. (1998) The Role of Proteolysis in the Processing and Assembly of 11S Seed Globulins. Plant Cell, 10, 343-357. https://doi.org/10.1105/tpc.10.3.343

[70] Dunaevsky, Y.E., Sarbakanova, S.T. and Belozersky, M.A. (1989) Wheat Seed Carboxypeptidase and Joint Action on Gliadin of Proteases from Dry and Germinating Seeds. Journal of Experimental Botany, 40, 1323-1329. https://doi.org/10.1093/jxb/40.12.1323

[71] Dunaevsky, Y.E., Belozersky, M.A. and Voskoboynikova, N.E. (1993) In Vitro Reconstitution of the Proteolytic System Responsible for Hydrolysis of the 13S Globulin in Buckwheat Seeds. FEBS, 324, 216-218.

https://doi.org/10.1016/0014-5793(93)81396-H

[72] Drzymała, A. and Bielawski, W. (2009) Isolation and Characterization of Carboxypeptidase III from Germinating Triticale Grains. Acta Biochimica et Biophysica Sinica, 41, 69-78. https://doi.org/10.1093/abbs/gmn008

[73] Bewley, J.D. and Black, M. (1994) Seeds: Physiology of Development and Germination. Plenum Press, New York. https://doi.org/10.1007/978-1-4899-1002-8 